\title{
Nuclear factor-like factor 2-antioxidant response element signaling activation by tert-butylhydroquinone attenuates acute heat stress in bovine mammary epithelial cells
}

\author{
X. L. Jin, ${ }^{*} \dagger$ K. Wang, $†$ L. Liu, ${ }^{*} \dagger$ H. Y. Liu, ${ }^{*} \dagger^{1}$ F.-Q. Zhao, ${ }^{*} \ddagger$ and J. X. Liu ${ }^{*}{ }^{1}$ \\ *Institute of Dairy Science, Key Laboratory of Molecular Animal Nutrition, Ministry of Education, and \\ †College of Animal Sciences, Zhejiang University, Hangzhou 310058, P.R. China \\ łLaboratory of Lactation and Metabolic Physiology, Department of Animal and Veterinary Sciences, University of Vermont, Burlington 05405
}

\begin{abstract}
Nuclear factor (erythroid-derived 2)-like factor 2 (Nrf2) is a transcription factor that binds to the antioxidant response element (ARE) in the upstream promoter region of many antioxidative genes. The Nrf2-ARE signaling plays a key role in the cellular antioxidant-defense system, but whether Nrf2 activation has protective effects against heat shock (HS) stress in mammary epithelial cells (MEC) remains unclear. The objective of this study was to determine whether tert-butylhydroquinone (tBHQ), a well-known Nrf2 activator, could attenuate heat stress-induced cell damage in MAC-T cells of the bovine MEC line. The MAC-T cells were exposed to HS $\left(42.5^{\circ} \mathrm{C}\right.$ for $\left.1 \mathrm{~h}\right)$ followed by recovery at $37^{\circ} \mathrm{C}$ to mimic HS. Compared with cells that were consistently cultured at normothermia $\left(37^{\circ} \mathrm{C}\right)$, the cell viability levels significantly decreased after HS stress. In parallel, heat stress increased the reactive oxygen species levels and induced cellular apoptosis and endoplasmic reticulum stress. The MAC$\mathrm{T}$ cells that were pretreated with tBHQ $(10 \mu M)$ for 2 $\mathrm{h}$ followed by HS had a reduction in the loss of cell viability. The tBHQ pretreatment significantly decreased cellular reactive oxygen species levels and stress-related marker gene expression. The tBHQ-treated MAC-T cells showed strong Nrf2-ARE signaling activation and a nuclear accumulation of Nrf2 and upregulated expression of Nrf2-ARE downstream genes. Small interfering RNA silencing of Nrf2 in HS-treated MAC-T cells almost completely abolished the cytoprotective effects by tBHQ. Overall, our results demonstrated that HS could cause cell damage in cultured bovine MEC, and that activation of Nrf2 by tBHQ could attenuate HSinduced cell damage.
\end{abstract}

Received February 15, 2016.

Accepted July 16, 2016.

${ }^{1}$ Corresponding authors: hyliu@zju.edu.cn and liujx@zju.edu.cn
Key words: antioxidation, bovine mammary epithelial cell, heat shock, tBHQ

\section{INTRODUCTION}

Dairy cows are sensitive to high temperature and easily suffer stress when the temperature-humidity index exceeds 72 , resulting in reduced milk productivity and economic losses (Rhoads et al., 2009; Bernabucci et al., 2014). Heat-stressed cows are mainly characterized by high body temperatures accompanied with increased respiration rates and water consumption and reduced feed intake and milk yield. Meanwhile, physiological disturbances, increased susceptibility to parasites, and disease occurrences are often observed in heat-stressed cows (Hahn, 1999). Under heat stress, cows have reduced antioxidant capacity and over-production of free radicals at systemic and cellular levels, suggesting that free radicals may play important roles in heat stress (Liu et al., 2010; Chauhan et al., 2014). Therefore, restoring the redox balance and strengthening the antioxidative capacity of the cows by supplying sufficient antioxidants or enhancing expression of antioxidant enzymes can be efficient management tools to protect dairy cow from heat stress.

Nuclear factor (erythroid-derived 2)-like factor 2 (Nrf2) is a transcription factor that binds to the antioxidant response element (ARE) in the upstream promoter region of many antioxidative genes. Signaling of Nrf2-ARE regulates expression of several different antioxidant enzymes involved in the elimination of reactive oxygen species (ROS), which are widely acknowledged as essential chemical agents that cause oxidative stress (Ma, 2013). We previously validated that the activation of Nrf2-ARE signaling promotes MAC-T cells, a bovine mammary epithelial cell (bMEC) line, survival following hydrogen peroxide treatment, which induces cellular oxidative damage as well as endoplasmic reticulum (ER) and mitochondria stress-induced cell death (Jin et al., 2016). For some drugs, Nrf2-ARE signaling 
activation contributes to their critical therapeutic or preventative effects in alleviating inflammation and combating other diseases in humans and in animals, such as various cancers, cardiovascular diseases, and Alzheimer diseases (Liby et al., 2005; Zhu et al., 2005). Activation of Nrf2 has been proven to be a molecular target candidate, and its promising effects have been shown to promote human and animal health (Ma, 2013).

Tert-Butylhydroquinone (tBHQ), a widely used food additive, is one of the most potent inducers of Nrf2 activity by increasing Nrf2 protein stability (Kraft et al., 2004). The stabilization of Nrf2 by tBHQ mainly occurs by blocking the ubiquitination and degradation of Nrf2 and by promoting its nuclear translocalization, which leads to increased ARE-mediated gene expression levels (Ma, 2013). These effects have been partly explained as a result of a direct reaction between the thiol group of Keap1 and tBHQ (Kraft et al., 2004; Gharavi et al., 2007; Wang et al., 2008). In vivo and in vitro studies have shown that the $\mathrm{BH}$-inducible Nrf2-mediated antioxidant response provides effective prophylaxis against various cellular or body dysfunctions (Eftekharzadeh et al., 2010). However, it is not known whether any protective effects exists on heat shock (HS) stress by the tBHQ activation of Nrf2-ARE in bMEC. Therefore, the aims of our study were to determine whether tBHQ can provide protection against heat stress-induced cell damage in cultured bMEC and to elucidate the roles of Nrf2 during this protection.

\section{MATERIALS AND METHODS}

\section{Chemical Reagents}

Tert-Butylhydroquinone (112941), 2', $7^{\prime}$-dichlorofluorescin diacetate (DCHF-DA, D6883), and alkaline phosphatase-conjugated secondary antibody (anti-rabbit $\operatorname{Ig} G$ ) were purchased from Sigma-Aldrich (St. Louis, MO). Dulbecco's modified Eagle medium (DMEM), fetal bovine serum, and penicillin-streptomycin were obtained from Life Technologies (Thermo Fisher Scientific, Boston, MA). Primary antibodies against $\beta$-tublin, Nrf2, heme oxygenase 1 (HO-1), thioredoxin reductase 1 (Txnrd-1), Bax, and Bcl2 were purchased from Abcam (Cambridge, MA), and primary antibodies that recognize total and phosphorylated eukaryotic initiation factor $2 \alpha(\mathbf{e I F} 2 \alpha)$ were obtained from Cell Signaling Technology (Danvers, MA). The commercial kits used in this study included a CCK-8 kit (Dojido, Kumamoto, Japan), RNApure kit (Aidlab Biotechnologies, Beijing, China), PrimeScript RT reagent (Takara, Dalian, China), SYBR premix EX Taq (Takara), RIPA lysis buffer (Beyotime, Haimen, China), and a BCA protein quantification kit (Beyotime). Other analytical grade chemicals were purchased from Sangon Biotechnology (Shanghai, China).

\section{Cell Culture and Acute HS Treatment}

The MAC-T cells were cultured in DMEM that was supplemented with $10 \%$ fetal bovine serum, $100 \mathrm{U} /$ $\mathrm{mL}$ penicillin $\mathrm{G}$, and $100 \mu \mathrm{g} / \mathrm{mL}$ streptomycin (SigmaAldrich; Huynh et al., 1991). The cells were maintained in a humidified incubator at $37^{\circ} \mathrm{C}$ in an atmosphere of $5 \% \mathrm{CO}_{2}$ and $95 \%$ air. The HS procedure was performed as described in our previous study (Liu et al., 2010). Briefly, the dispersed cells were seeded at a density of $1 \times 10^{5}$ cells $/ \mathrm{mL}$ and cultured for $24 \mathrm{~h}$ under normal conditions $\left(37^{\circ} \mathrm{C}\right)$ before the cells were challenged under a HS condition. The medium was replaced by $42.5^{\circ} \mathrm{C}$ prewarmed normal culture medium, then the cells were continuously maintained at this temperature for $1 \mathrm{~h}$. The cells were then returned to the normal culture condition, and the time point when the cells were returned was recorded as $0 \mathrm{~h}$. Cells consistently cultured in $37^{\circ} \mathrm{C}$ conditions were used as corresponding controls.

\section{Cell Viability and tBHQ Toxicity Determination}

Cell viability and the tBHQ toxicity evaluations were performed using a CCK-8 kit according to the manufacturer's instruction. For tBHQ toxicity determination, various concentrations of $\mathrm{BHHQ}$ were added to MAC-T cells for $24 \mathrm{~h}$. After optimal tBHQ concentration was defined, MAC-T cells were pretreated with tBHQ for $2 \mathrm{~h}$ before HS. At the end of the experiments, $10 \mu \mathrm{L} /$ well of CCK-8 reagent was added to the cells cultured in triplicate wells in the 96 -well plates. After incubation for $2 \mathrm{~h}$, the optical density at $450 \mathrm{~nm}$ was recorded with a microplate reader (Molecular Devices, Sunnyvale, CA).

\section{Intracellular ROS Detection}

A DCHF-DA staining assay was used to detect intracellular ROS as described in our previous study (Wang et al., 2015). Briefly, MAC-T cells were washed with PBS and incubated with fresh DMEM containing 10 $\mu M$ DCHF-DA at $37^{\circ} \mathrm{C}$ for $30 \mathrm{~min}$, then $1 \times 10^{6}$ cells were harvested and resuspended in PBS. The percentage of fluorescence-positive cells was determined with flow cytometry analysis (BD Biosciences, San Jose, CA) using excitation and emission filters of 488 and $530 \mathrm{~nm}$, respectively. 


\section{Nrf2 Immunofluorescence Microscopy}

The MAC-T cells were seeded in laser confocal Petri dishes (Coring Life Science, Lowell, CA), and the immunofluorescence staining was performed as previously reported (Jin et al., 2016). Briefly, cells were fixed with ice-cold methanol and acetone $(\mathrm{vol} / \mathrm{vol}=1: 1)$ solution for $30 \mathrm{~min}$, permeabilized with $0.5 \%$ PBS-Triton (Sangon Biotechnology, Shanghai, China) for $30 \mathrm{~min}$, and blocked by $10 \%$ goat serum-PBS for $30 \mathrm{~min}$. Then, the cells were incubated with a primary rabbit anti-Nrf2 antibody (1:200 dilution) overnight at $4^{\circ} \mathrm{C}$, followed by incubation in the dark with FITC-conjugated goat anti-rabbit IgG (1:500 dilution) and $4^{\prime}, 6$-diamidino2-phenylindole to stain the Nrf2 protein and the cell nuclei, respectively. The images were visualized under confocal laser microscopy (Leica, TSC SP5, Biberach, Germany).

\section{Quantitative Real-Time PCR}

Total RNA was extracted from MAC-T cells with an RNApure kit and reverse-transcribed with PrimeScript RT reagent (Takara). The cDNA products (1:10 dilution) were quantitated with real-time PCR, in which SYBR premix EX Taq and specific primers (Table 1) were utilized in a standard 2-step reaction on a 7500c Real-time PCR-detection system (Applied Biosystems, Carlsbad, CA). $\beta$-Actin was used for gene expression normalization.

\section{Western Blot}

The MAC-T cells were lysed in RIPA lysis buffer (50 $\mathrm{m} M \mathrm{pH} 7.5$ Tris $\cdot \mathrm{HCl}, 50 \mathrm{~m} M \mathrm{MNaCl}, 1 \% \mathrm{NP}-40,1 \%$ sodium deoxycholate, $0.1 \%$ SDS, $2 \mathrm{~m} M$ EDTA) with 1 $\mathrm{m} M$ (phenylmethylsulfonyl fluoride. The lysates were collected and centrifuged at $12,000 \times g$ for $10 \mathrm{~min}$ at $4^{\circ} \mathrm{C}$ to remove cell debris. Equal amounts of cell lysate $(20 \mu \mathrm{g})$ were used for Western blot analysis, as described previously (Wang et al., 2013).

\section{Small Interfering RNA Transfection}

The RNA interference was used to silence Nrf2 gene expression in MAC-T cells. Transient Nrf2 gene silencing was attained following small interfering (si)RNA transfection (sense 5'-CAGUUGAGGACUUCAAUGAdTdT- $3^{\prime}$ and antisense 5'-UCAUUGAAGUCCUCAACUGdTdT-3'; Jin et al., 2016). The $N r f 2$ siRNA $(50 \mathrm{n} M)$ or a negative control siRNA (sense 5'-UUCUCCGAACGUGUCACGUdTdT-3' and antisense 5 '-ACGUGACACGUUCGGAGAAdTdT-3') were transfected into MAC-T cells with the Lipofectamine 2000 reagent (Invitrogen, Carlsbad, CA) for $24 \mathrm{~h}$ before any subsequent treatments.

\section{Statistical Analysis}

All data are expressed as the means \pm standard error of the mean from the indicated numbers of independent experiments performed in triplicate. Statistical analysis was performed using one-way ANOVA, followed by Duncan's test for multiple comparisons. Differences were considered significant at $P<0.05$. All statistical tests were carried out using SPSS 17.0 (SPSS Inc., Chicago, IL).

\section{RESULTS}

\section{tBHQ Ameliorates Acute HS-Induced Cell Viability Loss}

The MAC-T cells were challenged with HS stress treatment $\left(42.5^{\circ} \mathrm{C}\right.$ for $\left.1 \mathrm{~h}\right)$, and their viabilities were

Table 1. Primers sequences used for quantitative real-time PCR

\begin{tabular}{|c|c|c|c|c|}
\hline Gene & Primer sequence & $\begin{array}{l}\text { Product } \\
\text { size (bp) }\end{array}$ & $\begin{array}{c}\text { Annealing } \\
\text { temperature }\left({ }^{\circ} \mathrm{C}\right)\end{array}$ & $\begin{array}{l}\text { GenBank } \\
\text { Accession No. }\end{array}$ \\
\hline GRP78 & $\begin{array}{l}\text { Forward (F): 5'-GACCCTGACTCGGGCTAAAT-3' } \\
\text { Reverse (R): 5'-TGGACAGCGGCACCATATG-3' }\end{array}$ & 243 & 60 & NM_001075148.1 \\
\hline $\operatorname{Bax}$ & $\begin{array}{l}\text { F: 5'-TGGACATTGGACTTCCTTCG-3' } \\
\text { R: 5'-CCAGCCACAAAGATGGTCAC-3' }\end{array}$ & 122 & 60 & NM_173894.1 \\
\hline Nrf2 & $\begin{array}{l}\text { F: 5'-AGGACATGGATTTGATTGAC-3' } \\
\text { R: 5'-TACCTGGGAGTAGTTGGCA-3' }\end{array}$ & 272 & 60 & NM_001011678.2 \\
\hline$H O-1$ & $\begin{array}{l}\text { F: 5'-GGCAGCAAGGTGCAAGA-3' } \\
\text { R: 5'-GAAGGAAGCCAGCCAAGAG-3' }\end{array}$ & 221 & 60 & NM_001014912.1 \\
\hline Txnrd-1 & $\begin{array}{l}\text { F: 5'-GTGTTCACGACTCTGTCGGT-3' } \\
\text { R: 5'-CTGCCTTCCACGAATCACCT-3' }\end{array}$ & 240 & 60 & NM_174625.3 \\
\hline$\beta$-actin & $\begin{array}{l}\text { F: 5'-CAAGGACCTCTACGCCAAC-3' } \\
\text { R: 5'-AGAAGCATTTGCGGTGGAC-3' }\end{array}$ & 257 & 60 & NM_173979.3 \\
\hline
\end{tabular}


registered during the subsequent recovery incubation period, up to $24 \mathrm{~h}$ at $37^{\circ} \mathrm{C}$. As shown in Figure $1 \mathrm{~A}$, cell viability immediately decreased after HS treatment, reached to its lowest point at $12 \mathrm{~h}$ ( $32 \%$ loss), and then slowly increased. The tBHQ-mediated cytotoxicity on the MAC-T cells following $24 \mathrm{~h}$ of treatment is shown in Figure $1 \mathrm{~B}$ and $\mathrm{tBHQ}$ was safe up to a $10 \mu M$ dosage. We next tested the effect of tBHQ pretreatment (0-10 $\mu M$ ) for $2 \mathrm{~h}$ on cell viability changes after $1 \mathrm{~h}$ of $\mathrm{HS}$ and a 12-h recovery incubation. As shown in Figure 1C, tBHQ pretreatment (5 and $10 \mu M$ ) significantly improved cell viability ( 86 and $85 \%$ compared with $78 \%$ in the HS group, $P<0.001)$ in the heat-stressed MAC-T cells in a dose-dependent manner.

\section{tBHQ Diminished HS-Induced ROS Accumulation and Alleviated Cellular Stress}

Several cellular stress responsive indices, including ROS accumulation, ER stress, and the expression of apoptosis-related genes, were examined in MAC-T cells after HS. As shown in Figure 2A, the ROS levels in MAC-T were elevated to $127 \pm 2$ (expressed as dichlorodihydrofluoresence mean value) after $42.5^{\circ} \mathrm{C}$ exposure and $3 \mathrm{~h}$ of recovery, compared with $88 \pm 9$ in the control cells that received no HS. This increase was close to the level of the cells exposed to $500 \mu \mathrm{M} \mathrm{H}_{2} \mathrm{O}_{2}$ for $3 \mathrm{~h}(116 \pm$ 3 , Figure 2A). The HS-induced ROS accumulation was significantly reduced by $5(102 \pm 1)$ and $10 \mu M(113 \pm$

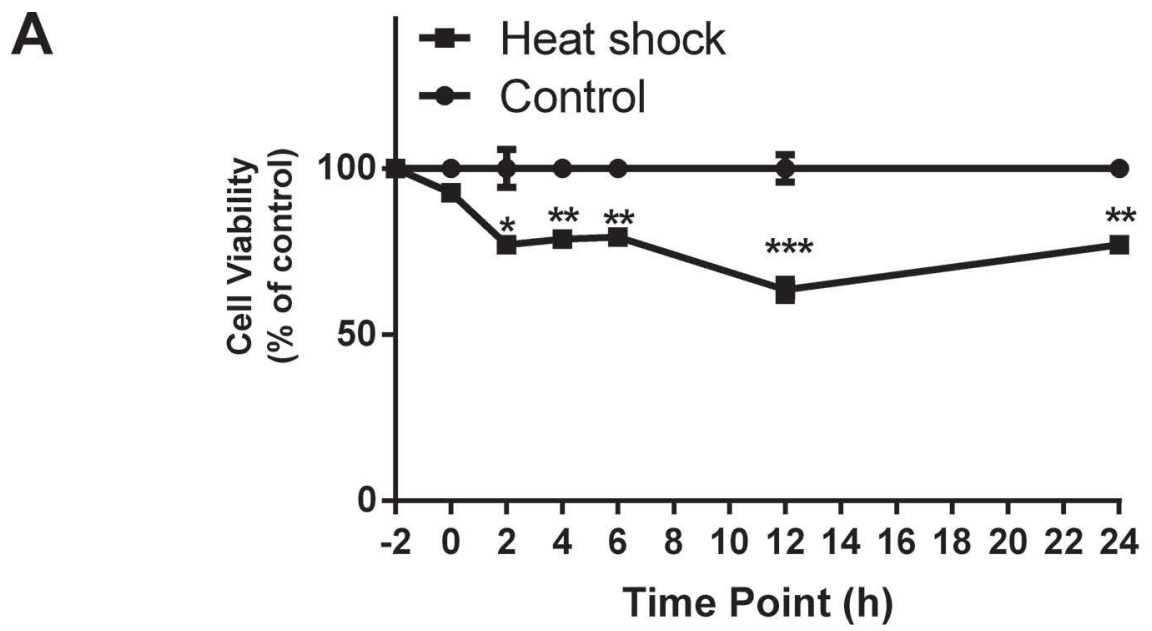

B

tBHQ toxcity

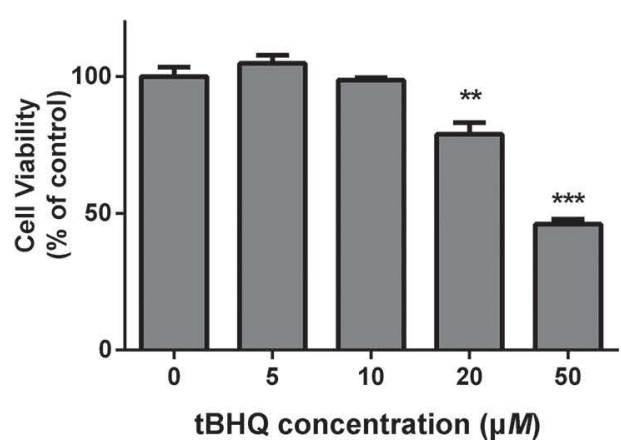

C

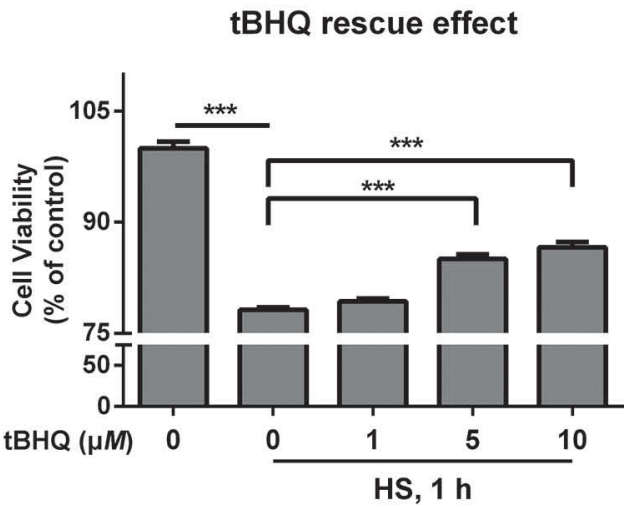

Figure 1. Tert-butylhydroquinone (tBHQ) protects MAC-T cells against heat shock (HS)-induced cell viability loss. (A) Cell viability was measured in MAC-T cells treated with acute HS $\left(42.5^{\circ} \mathrm{C}, 1 \mathrm{~h}\right)$ and then recovered at $37^{\circ} \mathrm{C}$ for the indicated time periods. The viability of the cells cultured consistently at $37^{\circ} \mathrm{C}$ (control) at each time point was set to 1 . (B) The MAC-T cells were treated with tBHQ at the indicated doses for $24 \mathrm{~h}$. The cell viability was measured and expressed as the percentage of the control cells (without tBHQ treatment). (C) The MAC-T cells were pretreated with tBHQ at the indicated doses for $2 \mathrm{~h}$, followed by HS and recovery at $37^{\circ} \mathrm{C}$ for $12 \mathrm{~h}$. The viability of the cells was measured and expressed as the percentage of the control cells that were consistently cultured at $37^{\circ} \mathrm{C}$ and received no tBHQ treatment. The data are expressed as the means \pm SEM from 4 independent experiments. ${ }^{*} P<0.05,{ }^{* *} P<0.01,{ }^{* * *} P<0.001$. 
1) tBHQ pretreatment for $2 \mathrm{~h}(P=0.002$; Figure $2 \mathrm{~A})$. Additionally, the expression of GRP 78 (a central regulator of ER stress) and CHOP (a key signaling component involved in ER stress-induced apoptosis), as well as eIF $2 \alpha$ phosphorylation (an initiator of the apoptotic pathway induced by ER stress), were examined as ER stress markers in MAC-T cells. As shown in Figures 2B and $2 \mathrm{C}, 10 \mu \mathrm{M}$ tBHQ pretreatment significantly suppressed HS-induced GRP78 and CHOP gene expression levels as well as the eIF $2 \alpha$ phosphorylation levels (Figures $2 \mathrm{~B}$ to 2D, left panels). Furthermore, HS exhibited a potential proapoptotic effect, as demonstrated by the upregulation of the proapoptotic protein, Bax, at both the mRNA and protein levels in HS-treated cells (Figures $2 \mathrm{~B}$ to $2 \mathrm{D}$, right panels). Pretreatment of the cells with $10 \mu M$ tBHQ decreased the HS-induced expression of Bax and increased expression of the anti-apoptotic protein, Bcl2 (Figures 2B to 2D, right panels).

\section{HS-Induced Nrf2-ARE Signaling Activation Is Augmented in tBHQ-Treated MAC-T Cells}

Heat shock-induced Nrf2-ARE signaling activation in MAC-T cells, with or without $2 \mathrm{~h}$ of $\mathrm{tBHQ}$ pretreatment, was elucidated by examining Nrf2 nuclear translocation and the ARE-driven gene expression levels. As shown in Figure 3A, hyperthermia treatment induced Nrf2 protein translocation into the nucleus of MAC-T cells. Pretreatment of MAC-T cells with $\mathrm{tBHQ}$ for 2 $\mathrm{h}$ showed further conspicuous nuclear translocation of Nrf2 and dramatic mRNA and protein upregulation of the ARE-driven genes, HO-1 and Txnrd1 (Figures $3 \mathrm{~A}$ to $3 \mathrm{C}$ ). Taken together, $\mathrm{tBHQ}$ treatment further boosted the Nrf2-ARE signaling activation that was induced by HS.

\section{tBHQ Cytoprotective Effects Against Heat Stress in MAC-T Cells}

To explore whether Nrf2-ARE signaling activation is essential for the cytoprotective effects by $\mathrm{tBHQ}$ against HS stress in MAC-T cells, siRNA-mediated Nrf2 gene silencing was performed. In the presence of tBHQ, Nrf2 siRNA transfection significantly decreased the Nrf2 mRNA levels (82\% decrease) and its target genes, $\mathrm{HO}-1$ and Txnrd1 (89 and $71 \%$ decrease, respectively; Figure $4 \mathrm{~A})$. Upon HS exposure, the viability of MAC-T cells that were transfected with Nrf2 siRNA was reduced $24 \%$ compared with cells transfected with control siRNA (Figure 4B). Moreover, Nrf2 depletion almost completely abrogated the tBHQ-mediated HS-induced cell death protection (Figure 4B). These data indicated that Nrf2-ARE signaling activation is essential for
tBHQ cytoprotective effects in heat-stressed MAC-T cells.

\section{DISCUSSION}

Numerous reports have confirmed the positive roles of Nrf2 in eliciting adaptive responses to diverse stresses by upregulating cellular antioxidant defense and restoring the cellular redox status (Magesh et al., 2012). In the current study, we investigated whether tBHQ, a well-known Nrf2 activator, could protect bMEC against HS-induced cell damage in vitro.

Many studies have investigated heat stress in dairy cows over the past several decades, as it causes significant economic loss in the dairy industry (Hammami et al., 2015; Perano et al., 2015). Dairy cows show several direct and indirect responses to heat overload, including changes in productive, physiological, health, and behavioral parameters (Allen et al., 2015). Researchers chose hyperthermia-treated bovine primary cells (such as hepatocytes and mammary epithelial cells) to mimic changes in cellular functions in animal tissues during heat stress (White et al., 2012; Han et al., 2015). These studies, including our previous one (Liu et al., 2010), showed that heat stress leads to a substantial effect on cell growth, morphology, and apoptosis. In the current study, we used immortalized MAC-T cells to establish a new HS stress model because of its effectiveness in siRNA treatments compared with primary bMEC. Treatment of the MAC-T cells at $42.5^{\circ} \mathrm{C}$ for 1 $\mathrm{h}$ resulted in thermal stress, which was comparable to results obtained in other epithelial or endothelial cell lines (Presley et al., 2010; Mu et al., 2014).

In vivo and in vitro studies have shown the involvement of oxidative stress in hyperthermia-induced cellular injury, as characterized by lipid peroxidation and oxidative damage to proteins and DNA (Nabenishi et al., 2012; Chen et al., 2014). Oxidative stress, which results from the imbalance between antioxidants and prooxidants, is mainly mediated by ROS. Reactive oxygen species are generated as by-products of normal cellular metabolism and serve as key signaling molecules in various physiological and pathological processes (Apel and Hirt, 2004). Our results confirmed that heat overload evoked superfluous intracellular ROS to levels that were even higher than the ROS levels induced by exogenous prooxidants $\left(\mathrm{H}_{2} \mathrm{O}_{2}\right)$ in MAC-T cells. The increased ROS production in heat-treated MAC-T cells provided direct evidence of a redox imbalance status in these cells, which is consistent with our previous study in primary bMEC, which demonstrated that hyperthermia treatment impairs the cellular antioxidant capacity by increasing the levels of malondialdehyde and lactate 


\section{A}

\section{ROS Production}

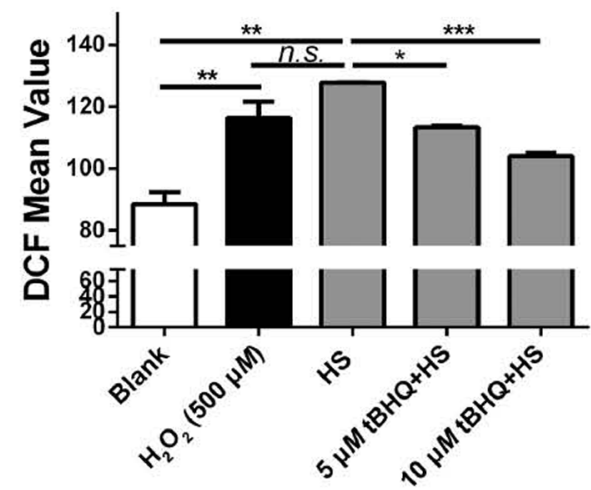

B
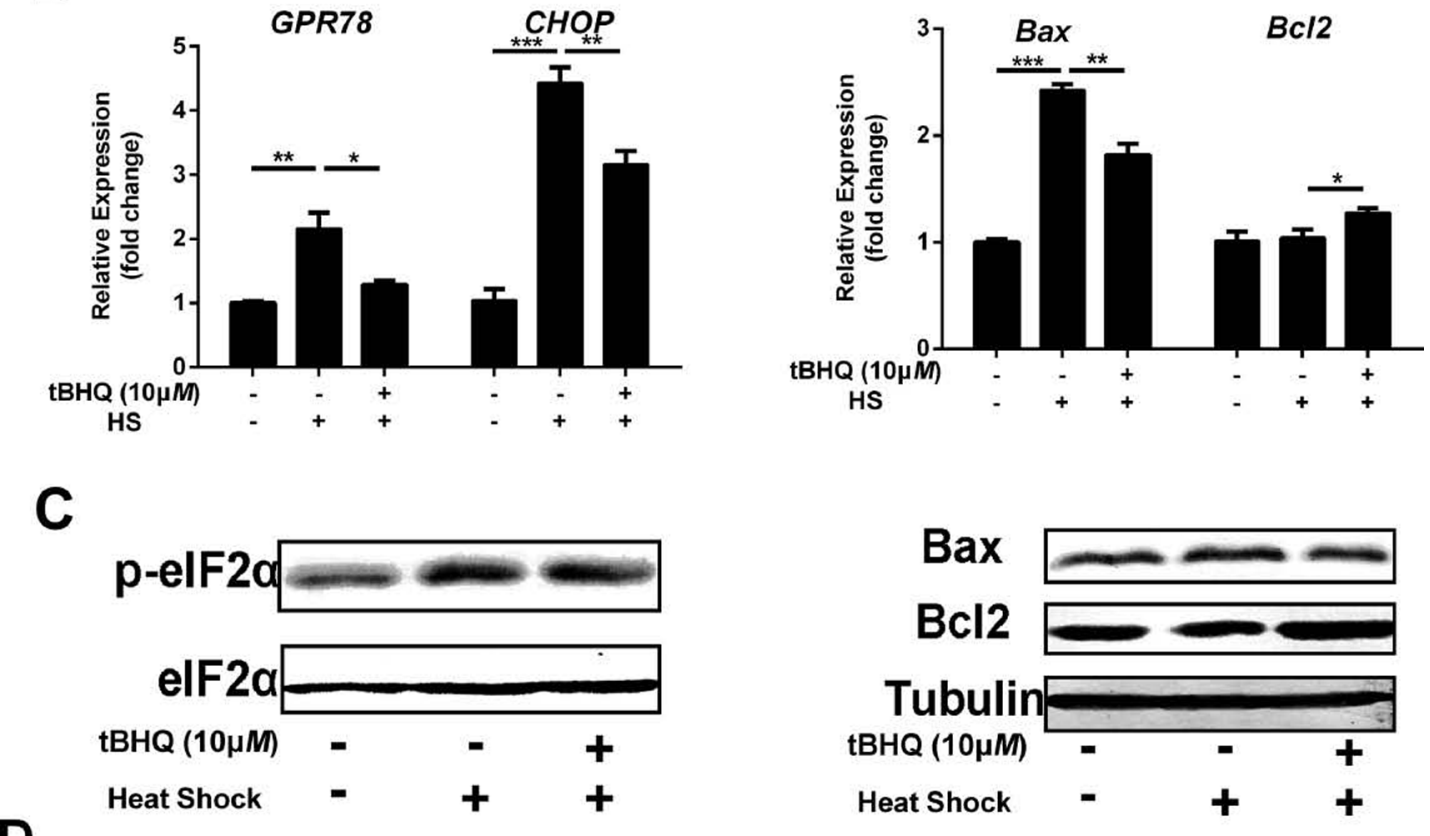

D
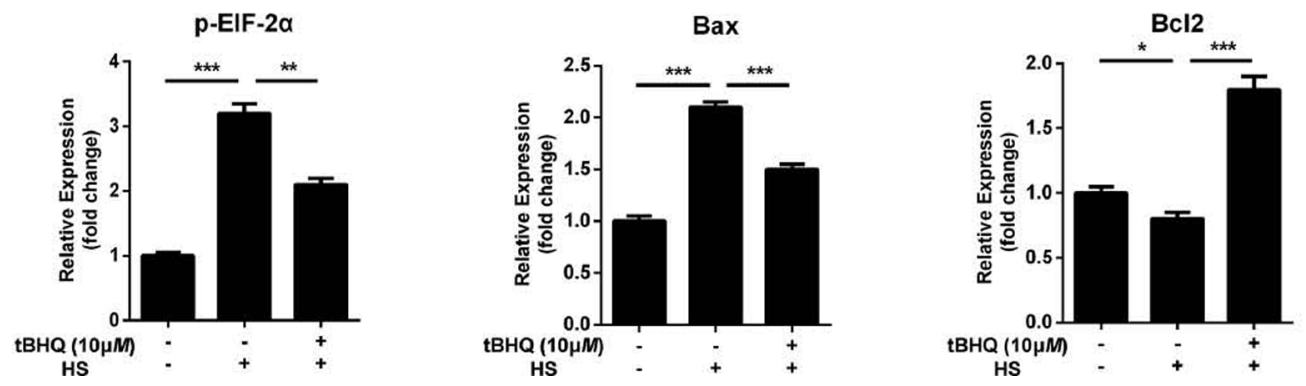

Figure 2. Pretreatment of MAC-T cells with tert-butylhydroquinone (tBHQ) attenuates heat shock (HS)-induced cellular stress responses. (A) The MAC-T cells were pretreated with or without tBHQ at the indicated doses for $2 \mathrm{~h}$ and then $\mathrm{HS}$ challenged $\left(42.5^{\circ} \mathrm{C}\right.$ for $\left.1 \mathrm{~h}\right)$ followed by recovery at $37^{\circ} \mathrm{C}$ for $3 \mathrm{~h}$. Cells cultured at $37^{\circ} \mathrm{C}$ with $500 \mu M \mathrm{H}_{2} \mathrm{O}_{2}$ were used as a control. The intracellular reactive oxygen species (ROS) levels were measured by flow cytometry. $\mathrm{DCF}=$ dichlorodihydrofluorescence. $(\mathrm{B}-\mathrm{D})$ The MAC-T cells were pretreated with $10 \mu M$ tBHQ for 2 $\mathrm{h}$, followed by HS and recovery at $37^{\circ} \mathrm{C}$ for $12 \mathrm{~h}$. The Bax, Bcl2, GPR 78, and CHOP mRNA expression levels were measured by real-time PCR and normalized to $\beta$-actin levels (B). The Bax, Bcl2, EIF-2 $\alpha$, and phosphorylated EIF-2 $\alpha$ protein levels were measured by Western blotting and normalized to $\beta$-tubulin levels (C). The band intensities of the Western blots were scanned and are quantitatively shown in (D), in which the phosphorylated EIF-2 $\alpha$ levels were relative to the total levels of EIF-2 $\alpha$ (left panel). The data are expressed as the means \pm SEM from 3 independent experiments. ${ }^{*} P<0.05,{ }^{* *} P<0.01,{ }^{* * *} P<0.001$. 
A

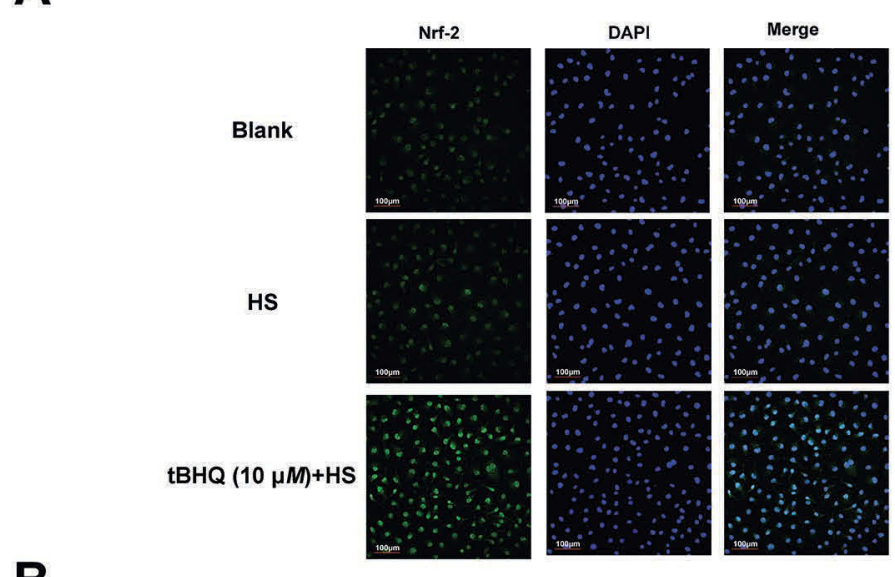

B

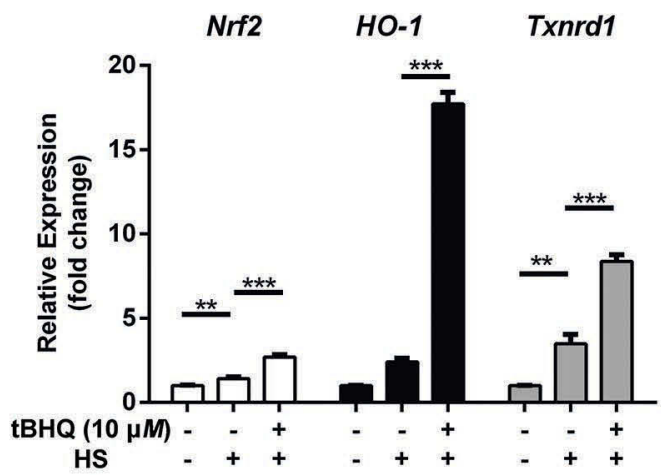

C
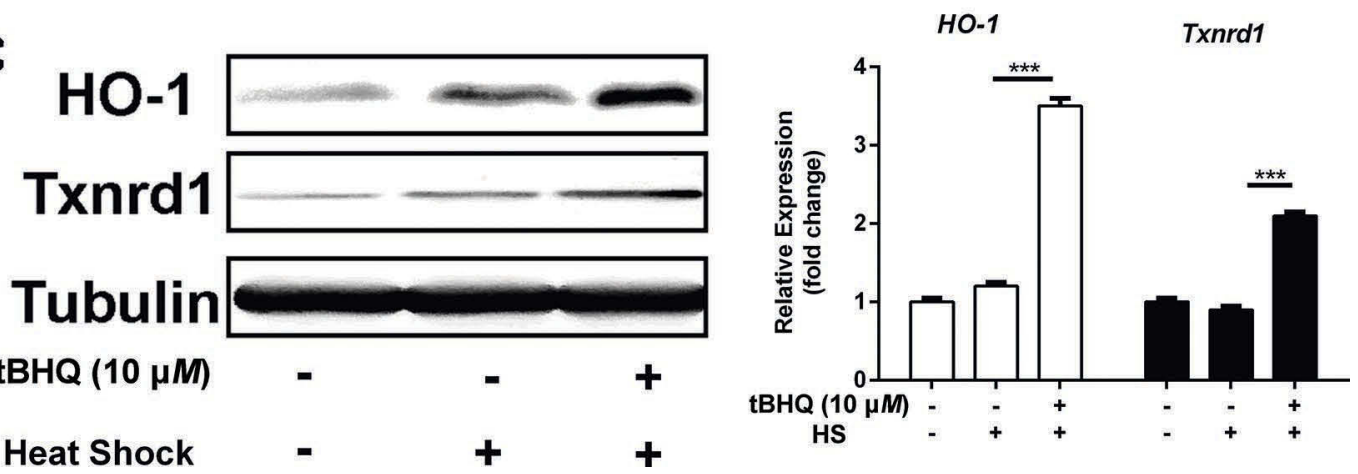

Figure 3. Pretreatment of MAC-T cells with tert-butylhydroquinone (tBHQ) further activates the Nrf2-ARE signaling that is induced by heat shock (HS). The MAC-T cells were pretreated with or without $10 \mu \mathrm{M}$ tBHQ for $2 \mathrm{~h}$, followed by heat shock $\left(42.5^{\circ} \mathrm{C}\right.$ for $\left.1 \mathrm{~h}\right)$ and recovery at $37^{\circ} \mathrm{C}$ for $12 \mathrm{~h}$. Cells that were consistently cultured at $37^{\circ} \mathrm{C}$ and received no tBHQ treatment were used as the control group (blank). (A) Confocal images of MAC-T cells stained with anti-Nrf2 and a fluorescein isothiocyanate-conjugated secondary antibody (green) and 4',6-diamidino-2-phenylindole (DAPI; blue), alone or together. (B) The Nrf2, HO-1, and Txnrd1 mRNA expression levels were measured by real-time PCR and normalized to $\beta$-actin mRNA levels. (C) The HO-1 and Txnrd1 protein levels were measured by Western blot analysis and normalized to $\beta$-tubulin (left panel), and the quantitative data are shown in the right panel. The data are expressed as the means \pm SEM from 3 independent experiments. ${ }^{* *} P<0.01,{ }^{* * *} P<0.001$. Color version available online. 
A
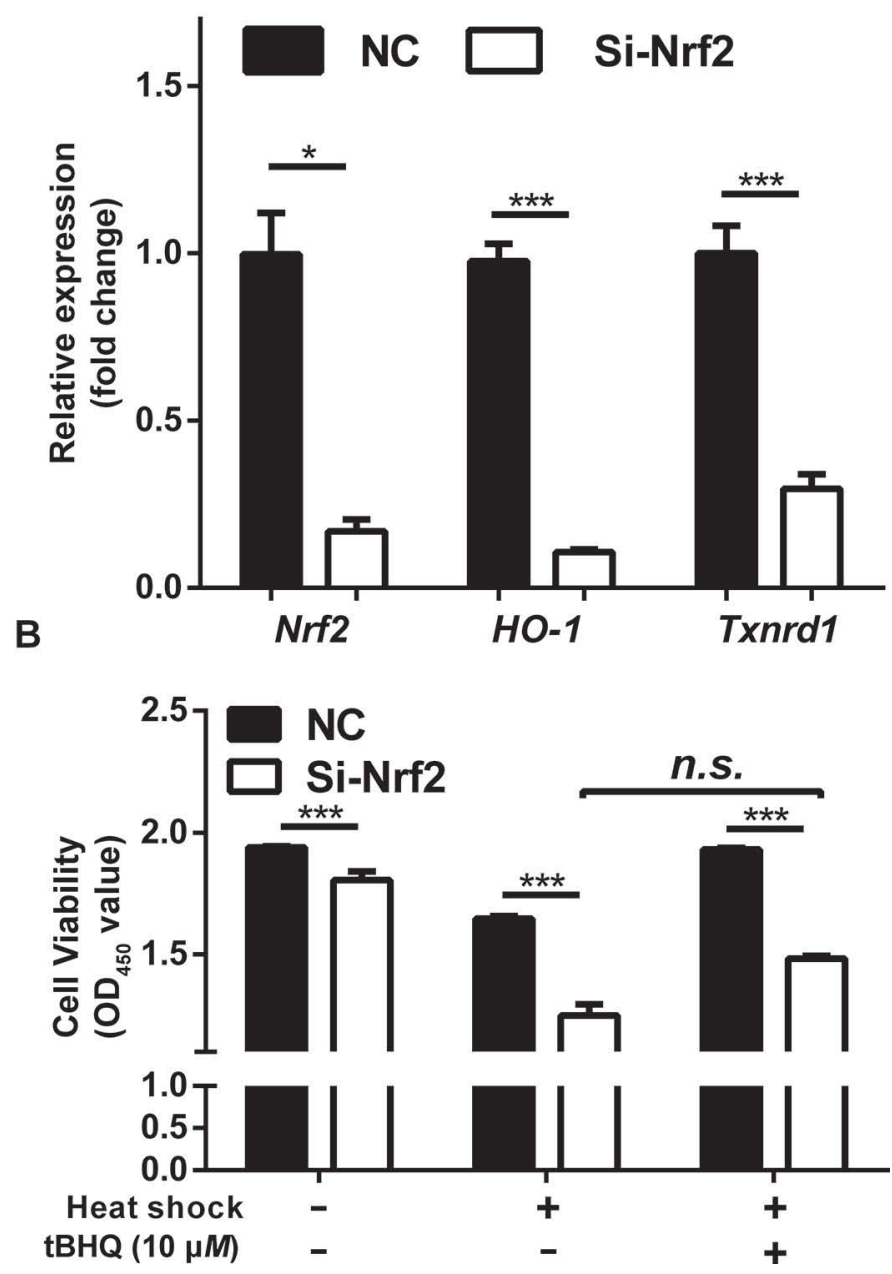

Figure 4. Signaling activation of Nrf2-ARE is essential for the cytoprotective effects of tert-butylhydroquinone (tBHQ) against heat shock (HS). (A) The MAC-T cells were transfected with Nrf2-specific small interfering RNA (Si-Nrf2) or a control small interfering RNA (NC) for $12 \mathrm{~h}$ and then treated with $10 \mu M \mathrm{tBHQ}$ for additional $2 \mathrm{~h}$. The Nrf2, HO-1, and Txnrd1 mRNA levels were measured by real-time PCR and normalized to $\beta$-actin levels. (B) After transfection with SiNrf2 or a control small interfering RNA (NC) for $12 \mathrm{~h}$, MAC-T cells were pretreated with or without $10 \mu M$ tBHQ for $2 \mathrm{~h}$, followed by heat shock $\left(42.5^{\circ} \mathrm{C}\right.$ for $\left.1 \mathrm{~h}\right)$ and recovery at $37^{\circ} \mathrm{C}$ for $12 \mathrm{~h}$ or consistent culture at $37^{\circ} \mathrm{C}$. The cell viability levels were determined. $\mathrm{OD}=$ optical density. The data are expressed as the means \pm SEM from 3 independent experiments. ${ }^{*} P<0.05,{ }^{* * *} P<0.001$.

dehydrogenase (Liu et al., 2010). We also previously observed that $\mathrm{H}_{2} \mathrm{O}_{2}$-induced ROS overproduction in MAC-T cells strongly upregulates the mRNA levels of ER stress markers (GRP78 and CHOP) and mitochondria-related cell apoptosis genes (Bcl2 and Bax; Jin et al., 2016). Because the intracellular ROS levels and mRNA and protein levels of ER stress and cellular apoptosis markers were increased in the HStreated cells in the current study, we propose that the detrimental effects caused by HS might be attributed to ROS-mediated oxidative damage in MAC-T cells, at least to some extent.

Accumulating evidence indicates that ER stressmediated apoptotic cell death plays a critical role in HS-induced cellular damage (Zhong et al., 2011; Bettaieb and Averill-Bates, 2015), although the underlying mechanisms remain elusive ( $\mathrm{Gu}$ et al., 2014). In the current study, we found that HS in MAC-T cells resulted in remarkably increased expression of the ER stress markers, GRP78 and CHOP, which correlated well with increased expression of the proapoptotic protein, Bax, and decreased cell viability.

We further explored the use of a commercially available antioxidant, $\mathrm{tBHQ}$, to protect bMEC that were exposed to HS. The tBHQ is widely used as a food and feed additive for humans and animals (Reeves et al., 1993; Wang et al., 2010; Braeuning et al., 2012); at low concentrations, it exerts cytoprotective effects in some cells by boosting cellular antioxidative defense systems, including the induction of phase II detoxifying (glutathione S-transferases) or antioxidant enzymes (HO-1, Txnrd1; Kraft et al., 2004). However, at high concentrations, tBHQ is toxic to cells (Ma, 2013). In the current study, tBHQ produced cytotoxicity in MAC-T cells when its concentration was higher than $10 \mu M$, which is much lower than its toxic concentrations in lymphocytes (Morzadec et al., 2014), bronchial epithelial cells (Chen et al., 2015), and hepatocytes (Duan et al., 2014). Because all of these previous studies used human cell lines, the sensitivity differences of MAC-T cells to tBHQ may represent cell type or species differences. More importantly, our study clearly demonstrated that pretreatment of MAC-T cells with tBHQ could significantly rescue them from HS-induced cell death.

Because tBHQ is known to enhance Nrf2-mediated transcriptional activation and subsequent antioxidant protection ( $\mathrm{Li}$ et al., 2005; Chen et al., 2015), we investigated whether Nrf2-ARE signaling activation might be responsible for the cytoprotective effects of tBHQ in MAC-T cells during HS. The Nrf2-ARE signaling activation induces the liberation of Nrf2 from its Keap1-mediated cytoplasmic entrapment, leading to its translocation to the nucleus. The translocated Nrf2 can then bind to the ARE element and start the transcription of several ARE-regulatory genes (Kensler et al., 2007). Both HO-1 and Txnrd1 are known Nrf-2 regulated genes that play important roles in combating cell stress and detoxification. Gene $\mathrm{HO}-1$ is highly inducible under several pathological conditions, including inflammation and heat stress (Bindu et al., 2013; Kikusato et al., 2015); Txnrd1 is a major component of the cell antioxidative thioredoxin system, and it defends cells 
against oxidative stress through its disulfide reductase activity and by regulating the protein dithiol and disulfide balance (Lu and Holmgren, 2014). Interestingly, our study showed that HS slightly activates Nrf-ARE signaling in MAC-T cells even without tBHQ treatment, indicating a possible self-defense mechanism of MAC-T cells to respond to HS. This is consistent with a previous study that showed that Nrf2 knockout mice were more sensitive to oxidative stress (Limonciel and Jennings, 2014). Importantly, we identified that the antihyperthermia effects of $\mathrm{tBHQ}$ were Nrf2-dependent. Knockdown of Nrf2 increased the sensitivity of MAC-T cells to HS and reduced the cytoprotective effects of tBHQ. Our data clearly showed that Nrf2 is necessary for cell survival during HS stress, and activated Nrf2 augmentation is a promising means to combating heat stress in dairy cows.

\section{CONCLUSIONS}

Our study provides the first evidence that tBHQ treatment can protect bMEC against heat stress in vitro. We also demonstrated that this protection was dependent on Nrf2-ARE signaling. The efficacy of tBHQ or other reagents that activate Nrf2-ARE signaling in protecting dairy cows from heat stress demands further study.

\section{ACKNOWLEDGMENTS}

This research was supported by grants from the National Key Research and Development Program of China (2016YFD0500503), National Natural Science Foundation of China (31672447), and China Agriculture Research System (CARS-37), Beijing.

\section{REFERENCES}

Allen, J. D., L. Hall, R. Collier, and J. Smith. 2015. Effect of core body temperature, time of day, and climate conditions on behavioral patterns of lactating dairy cows experiencing mild to moderate heat stress. J. Dairy Sci. 98:118-127.

Apel, K., and H. Hirt. 2004. Reactive oxygen species: Metabolism, oxidative stress, and signal transduction. Annu. Rev. Plant Biol. 55:373-399.

Bernabucci, U., S. Biffani, L. Buggiotti, A. Vitali, N. Lacetera, and A. Nardone. 2014. The effects of heat stress in Italian Holstein dairy cattle. J. Dairy Sci. 97:471-486.

Bettaieb, A., and D. A. Averill-Bates. 2015. Thermotolerance induced at a mild temperature of $40^{\circ} \mathrm{C}$ alleviates heat shock-induced ER stress and apoptosis in HeLa cells. Biochim. Biophys. Acta 1853:52-62.

Bindu, S., S. Mazumder, S. Dey, C. Pal, M. Goyal, A. Alam, M. S. Iqbal, S. Sarkar, A. A. Siddiqui, and C. Banerjee. 2013. Nonsteroidal anti-inflammatory drug induces proinflammatory damage in gastric mucosa through NF- $\mathrm{KB}$ activation and neutrophil infiltration: Anti-inflammatory role of heme oxygenase-1 against nonsteroidal anti-inflammatory drug. Free Radic. Biol. Med. 65:456-467.
Braeuning, A., S. Vetter, S. Orsetti, and M. Schwarz. 2012. Paradoxical cytotoxicity of tert-butylhydroquinone in vitro: what kills the untreated cells? Arch. Toxicol. 86:1481-1487.

Chauhan, S. S., P. Celi, B. Leury, I. Clarke, and F. Dunshea. 2014. Dietary antioxidants at supranutritional doses improve oxidative status and reduce the negative effects of heat stress in sheep. J. Anim. Sci. 92:3364-3374.

Chen, K.-L., H.-X. Li, X.-L. Xu, and G.-H. Zhou. 2014. The protective effect of rosmarinic acid on hyperthermia-induced $\mathrm{C} 2 \mathrm{C} 12$ muscle cells damage. Mol. Biol. Rep. 41:5525-5531.

Chen, Y., S. Wang, X. Fu, W. Zhou, W. Hong, D. Zou, X. Li, J. Liu, P. Ran, and B. Li. 2015. tert-Butylhydroquinone mobilizes intracellular-bound zinc to stabilize Nrf2 through inhibiting phosphatase activity. Am. J. Physiol. Cell Physiol. 309:C148-158.

Duan, X., D. Liu, X. Xing, J. Li, S. Zhao, H. Nie, Y. Zhang, G. Sun, and B. Li. 2014. Tert-butylhydroquinone as a phenolic activator of Nrf2 antagonizes arsenic-induced oxidative cytotoxicity but promotes arsenic methylation and detoxication in human hepatocyte cell line. Biol. Trace Elem. Res. 160:294-302.

Eftekharzadeh, B., N. Maghsoudi, and F. Khodagholi. 2010. Stabilization of transcription factor Nrf2 by tBHQ prevents oxidative stress-induced amyloid $\beta$ formation in NT2N neurons. Biochimie 92:245-253.

Gharavi, N., S. Haggarty, S. El-Kadi, and O. Ayman. 2007. Chemoprotective and carcinogenic effects of tert-butylhydroquinone and its metabolites. Curr. Drug Metab. 8:1-7.

Gu, Z. T., H. Wang, L. Li, Y. Liu, X. Deng, S. Huo, F. Yuan, Z. Liu, H. Tong, and L. Su. 2014. Heat stress induces apoptosis through transcription-independent p53-mediated mitochondrial pathways in human umbilical vein endothelial cell. Sci. Rep. 4:4469.

Hahn, G. L. 1999. Dynamic responses of cattle to thermal heat loads. J. Anim. Sci. 77:10-20.

Hammami, H., J. Vandenplas, M. L. Vanrobays, B. Rekik, C. Bastin, and N. Gengler. 2015. Genetic analysis of heat stress effects on yield traits, udder health, and fatty acids of Walloon Holstein cows. J. Dairy Sci. 98:4956-4968.

Han, Z.-Y., T. Mu, and Z. Yang. 2015. Methionine protects against hyperthermia-induced cell injury in cultured bovine mammary epithelial cells. Cell Stress Chaperones 20:109-120.

Huynh, H. T., G. Robitaille, and J. D. Turner. 1991. Establishment of bovine mammary epithelial cells (MAC-T): An in vitro model for bovine lactation. Exp. Cell Res. 197:191-199.

Jin, X., K. Wang, H. Liu, F. Hu, F. Zhao, and J. Liu. 2016. Protection of bovine mammary epithelial cells from hydrogen peroxideinduced oxidative cell damage by resveratrol. Oxidative Med. Cell Longev. 2016:2572175.

Kensler, T. W., N. Wakabayashi, and S. Biswal. 2007. Cell survival responses to environmental stresses via the Keap1-Nrf2-ARE pathway. Annu. Rev. Pharmacol. Toxicol. 47:89-116.

Kikusato, M., H. Yoshida, K. Furukawa, and M. Toyomizu. 2015. Effect of heat stress-induced production of mitochondrial reactive oxygen species on NADPH oxidase and heme oxygenase-1 mRNA levels in avian muscle cells. J. Therm. Biol. 52:8-13.

Kraft, A. D., D. A. Johnson, and J. A. Johnson. 2004. Nuclear factor E2-related factor 2-dependent antioxidant response element activation by tert-butylhydroquinone and sulforaphane occurring preferentially in astrocytes conditions neurons against oxidative insult. J. Neurosci. 24:1101-1112.

Li, J., D. Johnson, M. Calkins, L. Wright, C. Svendsen, and J. Johnson. 2005. Stabilization of Nrf2 by tBHQ confers protection against oxidative stress-induced cell death in human neural stem cells. Toxicol. Sci. 83:313-328.

Liby, K., T. Hock, M. M. Yore, N. Suh, A. E. Place, R. Risingsong, C. R. Williams, D. B. Royce, T. Honda, and Y. Honda. 2005. The synthetic triterpenoids, CDDO and CDDO-imidazolide, are potent inducers of heme oxygenase-1 and Nrf2/ARE signaling. Cancer Res. 65:4789-4798.

Limonciel, A., and P. Jennings. 2014. A review of the evidence that ochratoxin A is an Nrf2 inhibitor: Implications for nephrotoxicity and renal carcinogenicity. Toxins (Basel) 6:371-379. 
Liu, H. Y., K. Zhao, M. M. Zhou, C. Wang, J. A. Ye, and J. X. Liu. 2010. Cytoprotection of vitamin $\mathrm{E}$ on hyperthermia-induced damage in bovine mammary epithelial cells. J. Therm. Biol. 35:250253.

Lu, J., and A. Holmgren. 2014. The thioredoxin antioxidant system. Free Radic. Biol. Med. 66:75-87.

Ma, Q. 2013. Role of nrf2 in oxidative stress and toxicity. Annu. Rev. Pharmacol. Toxicol. 53:401-426.

Magesh, S., Y. Chen, and L. Hu. 2012. Small molecule modulators of Keap1-Nrf2-ARE pathway as potential preventive and therapeutic agents. Med. Res. Rev. 32:687-726.

Morzadec, C., M. Macoch, L. Sparfel, S. Kerdine-Römer, O. Fardel, and L. Vernhet. 2014. Nrf2 expression and activity in human T lymphocytes: Stimulation by $\mathrm{T}$ cell receptor activation and priming by inorganic arsenic and tert-butylhydroquinone. Free Radic. Biol. Med. 71:133-145.

Mu, T., G. H. Kong, Z. Y. Han, and H. X. Li. 2014. Cytoprotection of methionine on hyperthermia-induced damage in bovine mammary epithelial cells. Cell Biol. Int. 38:971-976.

Nabenishi, H., H. Ohta, T. Nishimoto, T. Morita, K. Ashizawa, and Y. Tsuzuki. 2012. The effects of cysteine addition during in vitro maturation on the developmental competence, ROS, GSH and apoptosis level of bovine oocytes exposed to heat stress. Zygote 20:249-259.

Perano, K. M., J. G. Usack, L. T. Angenent, and K. G. Gebremedhin. 2015. Production and physiological responses of heat-stressed lactating dairy cattle to conductive cooling. J. Dairy Sci. 98:52525261.

Presley, T., K. Vedam, L. J. Druhan, and G. Ilangovan. 2010. Hyperthermia-induced Hsp90. eNOS preserves mitochondrial respiration in hyperglycemic endothelial cells by down-regulating glut-1 and up-regulating G6PD activity. J. Biol. Chem. 285:38194-38203.

Reeves, P. G., F. Nielsen, and G. Fahey Jr. 1993. AIN-93 purified diets for laboratory rodents: Final report of the American Institute of Nutrition ad hoc writing committee on the reformulation of the AIN-76A rodent diet. J. Nutr. 123:1939-1951.

Rhoads, M. L., R. Rhoads, M. VanBaale, R. Collier, S. Sanders, W. Weber, B. Crooker, and L. Baumgard. 2009. Effects of heat stress and plane of nutrition on lactating Holstein cows: I. Production, metabolism, and aspects of circulating somatotropin. J. Dairy Sci. 92:1986-1997.

Wang, K., L. Hu, X. L. Jin, Q. X. Ma, M. C. Marcucci, A. A. L. Netto, A. C. H. F. Sawaya, S. Huang, W. K. Ren, and M. A. Conlon. 2015. Polyphenol-rich propolis extracts from China and Brazil exert anti-inflammatory effects by modulating ubiquitination of TRAF6 during the activation of NF- $\kappa$ B. J. Funct. Foods 19:464-478.

Wang, K., S. Ping, S. Huang, L. Hu, H. Xuan, C. Zhang, and F. Hu. 2013. Molecular mechanisms underlying the in vitro anti-inflammatory effects of a flavonoid-rich ethanol extract from Chinese propolis (poplar type). Evid. Based Complement. Alternat. Med. 2013:127672.

Wang, X. J., Z. Sun, W. Chen, Y. Li, N. F. Villeneuve, and D. D. Zhang. 2008. Activation of Nrf2 by arsenite and monomethylarsonous acid is independent of Keap1-C151: Enhanced Keap1-Cul3 interaction. Toxicol. Appl. Pharmacol. 230:383-389.

Wang, Y. M., J. Wang, C. Wang, B. Chen, J. Liu, H. Cao, F. Guo, and M. Vázquez-Añón. 2010. Effect of different rumen-inert fatty acids supplemented with a dietary antioxidant on performance and antioxidative status of early-lactation cows. J. Dairy Sci. 93:37383745 .

White, H. M., S. Koser, and S. Donkin. 2012. Regulation of bovine pyruvate carboxylase mRNA and promoter expression by thermal stress. J. Anim. Sci. 90:2979-2987.

Zhong, Q., B. Zhou, D. K. Ann, P. Minoo, Y. Liu, A. Banfalvi, M. S. Krishnaveni, M. Dubourd, L. Demaio, and B. C. Willis. 2011. Role of endoplasmic reticulum stress in epithelial-mesenchymal transition of alveolar epithelial cells. Am. J. Respir. Cell Mol. Biol. 45:498-509.

Zhu, H., K. Itoh, M. Yamamoto, J. L. Zweier, and Y. Li. 2005. Role of Nrf2 signaling in regulation of antioxidants and phase 2 enzymes in cardiac fibroblasts: protection against reactive oxygen and nitrogen species-induced cell injury. FEBS Lett. 579:3029-3036. 